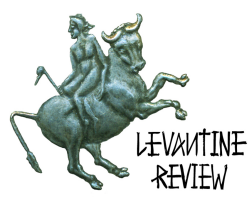

\title{
TOLERANCE AND COERCION IN THE SIRA OF IBN ISHAQ
}

\author{
Joseph S. Spoerl*
}

\section{INTRODUCTION}

It has become common for contemporary Muslim authors, especially when addressing nonMuslim audiences, to highlight one particular verse of the Koran, namely Sura 2 verse 256: "There is no compulsion in religion." Islamic apologists increasingly take this verse to be prescribing unconditional religious tolerance and use it to rebut depictions of Islam as intolerant. For example, the mid-twentieth century Egyptian Sheikh Al Azhar, Mahmud Shaltut, writes, "The Koran instructs us clearly that God did not wish people to become believers by way of force and compulsion, but only by way of study, reflection and contemplation." ${ }^{1}$ Shaltut adds, "there is absolutely no justification for anybody ... to hold ... that one of the ways in which the Mission of Islam has been propagated has been conversion by means of the sword or fighting."2 Shaltut describes Muhammad (570-632) as "the prophet who was the least inclined to use compulsion."3 The contemporary Swiss Muslim scholar Tariq Ramadan writes that this verse commands more than mere tolerance, "which smacks of condescension within a power relationship," but requires Muslims "to go beyond tolerance, to learn, listen, and recognize others' dignity." 4 Another contemporary Muslim writer, Louay Safi, insists that in Islamic ethics, "the general rule is that no one is to be forced to accept Islam." ${ }^{5}$ The American Shi' ite Muslim writer Reza Aslan describes the prohibition of religious compulsion as "one of the most important principles in the Quran."6

I will argue that this interpretation of Koran 2:256 is difficult to defend in the context of Muhammad's life as recounted in the earliest extant biography of Muhammad, the Life of the Prophet of God (Sirat Rasul Allah), written by Ibn Ishaq (d. ca. 767) and edited by Ibn

\footnotetext{
${ }^{1}$ Rudolph Peters, Jihad in Classical and Modern Islam: A Reader (Princeton: Marcus Wiener, 1996), p. 65.

2 Ibid., p. 69.

3 Ibid., p. 67.

4 Tariq Ramadan, In the Footsteps of the Prophet: Lessons from the Life of Muhammad (Oxford: Oxford University Press, 2007), p. 116.

${ }^{5}$ Louay M. Safi, Peace and the Limits of War: Transcending the Classical Conception of Jihad, second ed. (London and Washington: The International Institute of Islamic Thought, 2003), p. 25.

${ }^{6}$ Reza Aslan, No god but God: The Origins, Evolution, and Future of Islam (New York: Random House, 2005), p. 85.
} 


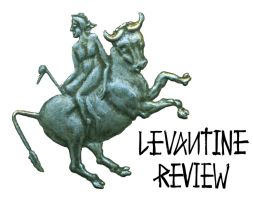

Hisham (d. ca. 833). ${ }^{7}$ F. E. Peters tells us that Ibn Ishaq's biography or sira forms the basis of virtually all later biographies of Muhammad in the Islamic tradition. ${ }^{8}$ It is, in Peters' words, "the classical and canonical biography of Muhammad." ${ }^{9}$ Omid Safi describes Ibn Ishaq's sira as "the oldest and most reliable" biography of Muhammad, stressing, like Peters, that "it provides the basis of all later biographies." 10 Moreover, for centuries, Ibn Ishaq's biography or sira has provided one of the main interpretive lenses through which Muslim scholars have tried to make sense out of the Koran by identifying the occasions of revelation (asbab al-nuzul) for its verses, which were revealed piecemeal to Muhammad under dramatically changing circumstances from 610 to $632 .{ }^{11} \mathrm{~A}$ related point is that classical Islamic exegetes of the Koran have followed the doctrine of abrogation, according to which contradictions in the Koran are to be resolved by studying the chronological order in which the verses were revealed to Muhammad. Of two contradictory verses, the one

${ }^{7}$ Rizwi Faizer and Andrew Rippin have argued recently that al-Waqidi's Kitab al-Maghazi is in fact earlier than Ibn Ishaq's sira. They reason that Ibn Hisham (d. c. 833) was younger than al-Waqidi (c. 748-822), and it is only in Ibn Hisham's abridged recension that we have Ibn Ishaq's sira. Rizwi Faizer ed., The Life of Muhammad: Al-Waqidi's Kitab al-Maghazi, trans. Rizwi Faizer, Amal Ismail, and AbdulKader Tayob (London and New York: Routledge, 2011), p. xiii. However, Ibn Hisham does keep his own annotations distinct from the (abridged) text of Ibn Ishaq, and Tabari and others seem to have had access to Ibn Ishaq's unabridged original text and quote from it at length, leading Alfred Guillaume to remark that "on the whole I think it is likely that we have the greater part of what I.I. wrote." Alfred Guillaume, The Life of Muhammad: A Translation of Ibn Ishaq's Sirat Rasul Allah (Oxford: Oxford University Press, 1955), p. xxxi. In fact, Guillaume's text is more than a translation but a reconstruction of Ibn Ishaq's unabridged text. As Guillaume writes, "It has been my aim to restore so far as is now possible the text of I.I. as it left his pen or as he dictated it to his hearers, from excerpts in later texts..." (Ibid., p. xxx). However, even if Faizer and Rippin were correct, it would not change anything in the present paper, since al-Waqidi never once mentions or even alludes to verse 2:256 of the Koran. Moreover, al-Waqidi's life of Muhammad contains as many cases of religious compulsion by Muhammad and his companions as Ibn Ishaq's: see e.g. Faizer, The Life of Muhammad: Al-Waqidi's Kitab alMaghazi, pp. 96, 99, 154, 168, 183, 199, 275-6, 316, 321, 349, 358, 403, 467, 473-4, 477-8, 481, 484, 511, 529, 548.

${ }^{8}$ Francis Peters observes, "all the earliest surviving versions of Muhammad's life rely heavily on Ibn Ishaq's original Sira." F. E. Peters, "The Quest of the Historical Muhammad," International Journal of Middle East Studies, 23 (1991), p. 304.

${ }^{9}$ F.E. Peters, Muhammad and the Origins of Islam (Albany: State University of New York Press, 1994), p. 49.

10 Omid Safi, Memories of Muhammad: Why the Prophet Matters (New York: HarperCollins, 2009), p. 105.

11 See "Tafsir" in John L. Esposito ed. The Oxford Encyclopedia of the Islamic World (Oxford: Oxford University Press, 2009), Vol. 5, pp. 299-306. 


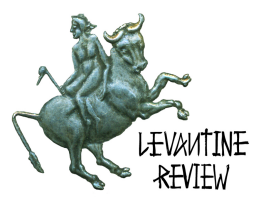

revealed later in Muhammad's life was said to abrogate the other. ${ }^{12}$ In fact, the apparent contradiction between verse 2:256 and the later verse 9:5 led some classical exegetes to assert that 2:256 has been abrogated by 9:5.13 Thus, classical Muslim scholars have always held that interpretation of the Koran requires the detailed knowledge of Muhammad's life that can be gained by reading the sira of Ibn Ishaq.

Another important point is that the Koran repeatedly commands Muslims to obey and imitate Muhammad; ${ }^{14}$ indeed, Islamic orthodoxy insists that Muhammad enjoyed divinely granted immunity from sin and error. ${ }^{15}$ Yet one can only learn of the teachings and example of Muhammad by recourse to the sira and the (later) hadith collections, since the Koran tells us almost nothing about Muhammad. Thus, the study of these materials is as essential to a traditional Muslim as the study of the Koran. As the great legal scholar Muhammad alShafi (767-820) puts it, "he who accepts the duties to God [laid down] in His Book should accept the sunna of the Apostle by God's command ordering his creatures to obey the Apostle and have recourse to his decision." 16 Tradition has it that Muhammad told his followers, "None of you believes until I am more beloved to him than his wife, child, self, and all people," and classical Islamic scholars explain what this means as follows: "Love of the Prophet... means the will to obey him and not disobey him, this being one of the obligations of Islam."17 Sahih Bukhari, the most respected of the collections of Muhammad's sayings (hadith), quotes Muhammad as saying, "whoever obeys me, obeys Allah, and whoever disobeys me, disobeys Allah."18

12 David S. Powers, "The Exegetical Genre nasikh al-Quran wa mansukhuhu," in Andrew Rippin ed., Approaches to the History of the Interpretation of the Quran (Oxford: Clarendon Press, 1988), pp. 117-138, and David Bukay, "Peace or Jihad? Abrogation in Islam," The Middle East Quarterly 14 (2007), pp. 3-11, http://www.meforum.org/1754/peace-or-jihadabrogation-in-islam

13 See Powers, "The Exegetical Genre nasikh al-Quran wa mansukhuhu," pp. 137-138.

${ }^{14}$ E.g. Koran 3:32, 3:132, 4:13, 4:59, 4:69, 5:92, 8:1, 8:20, 8:46, 9:71, 24:47, 24:51, 24:52, 24:54, 24:56, 33:33, 33:36, 47:33, 49:14, 58:13, 64:12.

15 W. Madelung, "Isma," in H.A.R. Gibb ed., The Encyclopedia of Islam (Leiden: Brill, 1954), Vol. 4, pp. 182-184.

${ }^{16}$ Majid Khadduri ed. and trans., al-Shafi's Risala: Treatise on the Foundations of Islamic Jurisprudence, second ed. (London: The Islamic Texts Society, 1987), p. 76.

${ }^{17}$ Ahmad ibn Naqib al-Misri, Reliance of the Traveller: A Classic Manual of Islamic Sacred Law, Nuh Ha Mim Keller trans., rev. ed. (Beltsville, MD: Amana Publications, 1994), p. 700. 18 Sahih Bukhari, trans. M. Muhsin Khan, Volume 9, Book 89, Number 251, at http://www.usc.edu/schools/college/crcc/engagement/resources/texts/muslim/hadith/ bukhari/ 


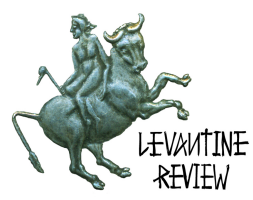

It is, of course, possible to challenge the historical reliability of Ibn Ishaq's sira and, with it, his interpretation of the Koran. ${ }^{19}$ This essay will be approaching the Koran, especially verse $2: 256$, through the lens of the sira, and I will prescind altogether from the question of the sira's accuracy. Those who reject the sira as radically unreliable must either draw a new portrait of Muhammad on very limited evidence, a rather daunting task, or admit that we know little or nothing about the "real" Muhammad. This latter conclusion may well imply that much of the Koran, including perhaps verse 2:256, is incomprehensible to us. In any event, rejecting the traditional materials on Muhammad, such as the sira, would seem to be unacceptable for a traditional Muslim, since doing so would make it impossible to fulfill the central Islamic duty to obey and imitate Muhammad. There are doubtless new interpretive strategies for less traditionally-minded Muslims to explore, ${ }^{20}$ but those will not be the focus of this paper, which is restricted to tolerance and coercion as depicted in the sira of Ibn Ishaq.

\section{COMPULSTION AGAINST “PEOPLE OF THE BOOK”: 2:256 IN THE CONTEXT OF THE SIRA 21}

In nearly seven hundred pages, Ibn Ishaq alludes to verse 2:256 only once, when quoting a letter from Muhammad to the Jews of Khaybar. Before getting to that passage, however, we must understand its context within Ibn Ishaq's narrative. That context is Ibn Ishaq's lengthy diatribe against Muhammad's Jewish and non-Jewish adversaries in Medina, a diatribe that he positions between his accounts of the hijra (Muhammad's flight to Medina in 622) and the battle of Badr (in 624), suggesting that the hostility between Muhammad and the Jews commenced almost immediately after Muhammad's arrival in Medina. ${ }^{22}$

${ }^{19}$ On the question of Ibn Ishaq's reliability, see: F. E. Peters, "The Quest of the Historical Muhammad," International Journal of Middle East Studies, 23 (1991), pp. 291-315, reprinted in F.E. Peters, Muhammad and the Origins of Islam, pp. 257-268, and Fred M. Donner, Muhammad and the Believers: At the Origins of Islam (Cambridge, MA and London, UK: The Belknap Press of Harvard University Press, 2010), pp. 50-56 and 242-244. For a more trusting view of Ibn Ishaq's reliability, see W. Montgomery Watt, "The Reliability of Ibn Ishaq's Sources," in Watt, Early Islam: Collected Articles (Edinburgh: Edinburgh University Press, 1990), pp. 13-23. A very skeptical view of Ibn Ishaq is that of Patricia Crone and Michael Cook, Hagarism: The Making of the Muslim World (Cambridge: Cambridge University Press, 1980).

${ }^{20}$ For some ideas along these lines, see Joseph S. Spoerl, "Islam and War: Tradition vs. Modernity," Comparative Islamic Studies 4 (2008), pp. 181-212 at pp. 206-210.

21 This section focuses on the theological or ideological conflict between Muhammad and the Jews as recounted by Ibn Ishaq's sira; for further discussion of this topic, see Joseph S. Spoerl, "Muhammad and the Jews According to Ibn Ishaq," The Levantine Review 2 (2013), pp. 84-103, http://ejournals.bc.edu/ojs/index.php/levantine/article/view/5084

${ }^{22}$ Alfred Guillaume, The Life of Muhammad: A Translation of Ibn Ishaq's Sirat Rasul Allah (Oxford: Oxford University Press, 1955), pp. 239-79. 


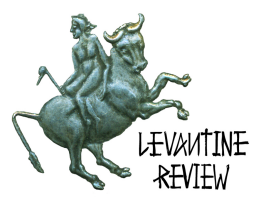

Much of this diatribe is a commentary on Sura 2, "The Cow."23 This Sura, Ibn Ishaq tells us, was sent down shortly after the hijra, in reference to the Jewish rabbis and hypocrites, ${ }^{24}$ who were Muhammad's worst opponents in Medina. Shortly after Muhammad's arrival in Medina, "the Jewish rabbis showed hostility to the apostle in envy, hatred, and malice, because God had chosen His apostle from the Arabs." 25 The Jewish rabbis were "rancorous opponents of the apostle... who asked questions and stirred up trouble against Islam."26 "[T]he rabbis and unbelieving Jews...used to ask him questions and annoy him in confusing truth with falsehood."27

In Sura 2, prior to verse 256, there are no fewer than ten verses that accuse the Jews of dishonesty vis-à-vis their own scriptures. ${ }^{28}$ Ibn Ishaq's narrative places these verses squarely in the context of a fierce debate between Muhammad and the rabbis about whether the Torah identifies Muhammad as a prophet that the Jews must follow. Ibn Ishaq portrays the Jews as knowing that Muhammad is a prophet yet rejecting him anyway. ${ }^{29}$ According to Ibn Ishaq, God said to Muhammad about the Jews, "they disbelieve that thou art mentioned (in the books) they have and they reject the covenant which was made with them with reference to thee. They disbelieve in what has come to thee and in what they have already which others brought to them..."30 The Jews of Medina are told about Muhammad, "You know that he is the apostle of God. You will find him described in your Torah and even named." 31 Muhammad's close companion Abu Bakr exhorts a rabbi in a Jewish school in Medina "to fear God and become a Muslim because he [the rabbi] knew that Muhammad was the apostle of God who brought the truth from Him and that they would find it written in the Torah and the Gospel."32 "The most learned man living in the Torah," a rabbi named Abdullah bin Suriya, is portrayed as confessing to Muhammad: "they [the Jews] know right well ... that you are a prophet sent (by God) but they envy you." 33 The Jews are consistently portrayed as liars precisely because they refuse to accept Muhammad as a prophet: "The Jews are a nation of liars...a treacherous, lying, and evil people."34

\footnotetext{
23 Ibid., pp. 247-70 (these pages also include commentary on Suras 3, 4, and 5).

24 The "hypocrites" were pagans in Medina who converted to Islam without really believing.

25 Ibid., p. 239.

26 Ibid., p. 240.

27 Ibid., p. 256.

28 Verses 59, 75, 79, 89, 101, 140, 146, 159-60, 174, 211.

29 Guillaume, The Life of Muhammad, p. 242, and passim.

30 Ibid. p. 248; cf. pp. 249-50, 252, 254, 255.

31 Ibid., p. 241.

32 Ibid., p. 263.

33 Ibid., pp. 266-7.

34 Ibid., p. 241. In his Kitab al-Maghazi, al-Waqidi also portrays the Jews as knowing that Muhammad is a prophet described and foretold in the Torah, yet dishonestly denying this
} 


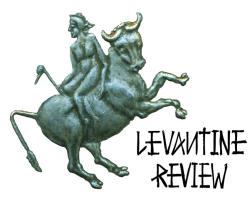

Ibn Ishaq portrays Muhammad as becoming much more threatening and aggressive towards the Jews after his first great military victory, over the pagan Quraysh, at the battle of Badr in 624:

When God smote Quraysh at Badr, the apostle assembled the Jews in the market of the Banu Qaynuqa when he came to Medina and called on them to accept Islam before God should treat them as He had treated Quraysh. ${ }^{35}$ The apostle... addressed them as follows: 'O Jews, beware lest God bring upon you the vengeance that he brought upon Quraysh and become Muslims. You know that I am a prophet who has been sent-you will find that in your scriptures and God's covenant with you.'36

This is obviously a threat: "Become Muslims or else I will crush you militarily as I crushed the Quraysh at Badr." Indeed, Ibn Ishaq portrays the Jews as understanding clearly that they are being threatened with war if they do not convert, for they respond: " 0 Muhammad... Do not deceive yourself because you encountered a people with no knowledge of war and got the better of them; for by God if we fight you, you will find that we are real men!" 37 Clearly the idea that "there shall be no compulsion in religion" is not understood by Muhammad as precluding such a threat aimed at the Jews. Muhammad seems to regard forced conversion of the Jews as justified because it is only requiring them to live up to their covenant with God, rather like a judge enforcing a contract.

If we consider that Muhammad was illiterate (and certainly not literate in Hebrew ${ }^{38}$ ), then we can understand why the literate rabbis would become irritated and that the debate would become "rancorous." We occasionally catch glimpses of the bafflement that Muhammad's claims elicited from the rabbis: "He has not brought us anything we recognize and he is not the one we spoke of to you." "No covenant was ever made with us about Muhammad." "O Muhammad, you have not brought us anything we recognize."39 "'Is it true, Muhammad, that what you have brought is the truth from God? For our part, we cannot see

out of envy. See Faizer, The Life of Muhammad: Al-Waqidi's Kitab al-Maghazi, pp. 87, 128, 160, 179-80, 234-5, 246-7.

35 Guillaume, The Life of Muhammad, p. 260.

36 Ibid., p. 363. Ibn Ishaq here (unlike in the passage on p. 260) tells us that this message was aimed specifically at the Banu Qaynuqa, but Muhammad's claim about the Jewish scriptures and covenant would clearly apply to all the Jews.

37 Ibid., p. 363.

38 See ibid. p. 267, where Ibn Ishaq implies that Muhammad cannot read the Torah for himself, since he relies on Abdullah bin Sallam to identify the verse prescribing stoning for adultery. Al-Waqidi clearly implies that Muhammad cannot read Arabic: see Faizer, The Life of Muhammad: Al-Waqidi's Kitab al-Maghazi, p. 307.

39 Guillaume, The Life of Muhammad, p. 257. 


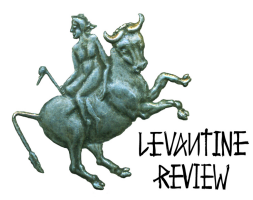

that it is arranged as the Torah is.' He [Muhammad] answered, 'You know quite well that it is from God; you will find it written in the Torah which you have."'40

According to Ibn Ishaq, then, Sura 2 is a lengthy polemic against the Jews and hypocrites of Medina, and the main charge against the Jews is that the rabbis know that Muhammad is identified in the Torah as a prophet they must follow yet lie about this. This is the context for the one and only reference to verse 2:256 in the entire biography:

The apostle wrote to the Jews of Khaybar...'In the name of God the compassionate the merciful from Muhammad the apostle of God friend and brother of Moses who confirms what Moses brought. God says to you, O scripture folk, and you will find it in your scripture, "Muhammad is the apostle of God; and those with him are severe against the unbelievers, merciful among themselves."... Do you find in what He has sent down to you that you should believe in Muhammad? If you do not find that in your scripture then there is no compulsion upon you. "The right path has been plainly distinguished from error" so I call you to God and His prophet' [note omitted].41

Ibn Ishaq does not give a date for this letter to the Jews of Khaybar, but, even though he positions this passage before his own account of Badr, it almost certainly would have been written several years after the battle of Badr, which took place in 624. Khaybar was a Jewish farming community some ninety miles north of Medina, ${ }^{42}$ and it is highly unlikely that Muhammad would have taken much note of it until after his expulsion of the Jewish tribe of the Banu al-Nadir from Medina in 626.43 Some of the Banu al-Nadir settled in Khaybar, ${ }^{44}$ and they then played a role in planning the attack on Medina that led to the Battle of the Ditch in 627.45 After massacring the last Jewish tribe in Medina in $627^{46}$ and neutralizing the pagan Quraysh in Mecca by means of the truce of Hudaybiyya in 628,47 Muhammad would turn to the now-isolated Jews of Khaybar and conquer them in the same year. ${ }^{48}$ It follows that Muhammad's letter to the Jews of Khaybar would have been

40 Ibid., p. 269; cf. p. 270.

41 Ibid., p. 256.

42 Maxime Rodinson, Muhammad, Anne Carter trans. (New York: The New Press, 1980), p. 253.

${ }^{43}$ Guillaume, The Life of Muhammad, pp. $437 \mathrm{ff}$.

44 Ibid., p. 437.

45 Ibid., p. 450.

46 Ibid., pp. $461 \mathrm{ff}$.

${ }^{47}$ Ibid., pp. 499 ff.

48 Ibid., pp. $510 \mathrm{ff}$. 


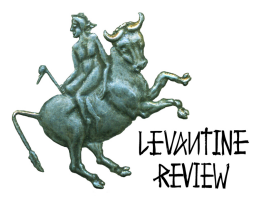

composed sometime between the expulsion of the Banu al-Nadir in 626 and the conquest of Khaybar in 628-that is, two to four years after the battle of Badr. ${ }^{49}$

Note that in his one-and-only reference to verse 2:256, Muhammad phrases the verse conditionally: "If you (the Jews of Khaybar) do not find in your scriptures that you should believe in Muhammad, then there is no compulsion upon you." Moreover, in the very same paragraph, and in numerous other passages, as we have seen, Muhammad asserts emphatically that the condition is not fulfilled. Muhammad insists that the Jews do find in their book - the Torah-unmistakable passages that identify Muhammad by name as a prophet that the Jews are obliged by their covenant to accept and follow. Muhammad's conditional statement is logically equivalent to its contrapositive: "If there is compulsion upon you, then you do find it in your scriptures that you should believe in Muhammad." ${ }^{50}$ It is only a short step from this to another statement: "If there is compulsion upon you, it is because you find it in your scriptures that you should believe in Muhammad." This appears to be Muhammad's true meaning. ${ }^{51}$ Why else would he include here the veiled threat that Muslims "are severe against the unbelievers, merciful among themselves?" Since he had threatened the Jews in Medina after Badr with violence if they did not convert and then followed through on those threats, the Jews of Khaybar would have understood this message very well. When he says, "'The right path has been plainly distinguished from error' so I call you to God and His prophet," what he really means is that the covenantal duty of the Jews to accept him as a prophet is so obvious that they have no right to refuse conversion to Islam - the message that he had been conveying to the Jews ever since the hijra. Muhammad is, after all, the "friend and brother of Moses who confirms what Moses brought." The Jews have no more right to reject him than to reject Moses.

The letter to the Jews of Khaybar must be understood in light of his ultimatum a couple of years earlier to the Jews of Medina after his return from Badr. It seems implausible that Muhammad would be any less harsh in addressing the Jews of Khaybar than he had been in addressing the Jews of Medina, especially since his relations with the Jews had become

${ }^{49}$ For other exegetical traditions in Islamic history regarding verse 2:256, see Yohanan Friedmann, Tolerance and Coercion in Islam: Interfaith Relations in the Muslim Tradition (Cambridge: Cambridge University Press, 2003), pp. 100-1.

50 In general, any conditional statement "If $A$, then B" is logically equivalent to "If not B, then not A," and vice-versa. Thus, "If combustion occurs, then oxygen is present" is equivalent to "If oxygen is not present, then combustion does not occur." See Irving M. Copi and Carl Cohen, Introduction to Logic, eighth ed. (New York: Macmillan, 1990), p. 305. ${ }^{51}$ Another possibility is that Muhammad means this: "If you do not find it in your scriptures, then there is no compulsion in the sense that I cannot make you want to be Muslims, but I will compel you to conform to Islam outwardly, since as a prophet I have the right and duty to force you to honor your covenant." See the discussion of Rudi Paret's thesis about verse 2:256 in the conclusion, below. 


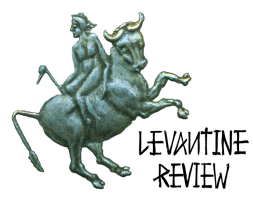

steadily more hostile after Badr. We have no choice but to conclude, therefore, that the one and only allusion to the verse "there is no compulsion in religion" in the entire sira not only is not an unconditional endorsement of religious liberty. It is in fact a not-so-thinly-veiled threat by Muhammad that he will crush the Jews of Khaybar militarily if they do not convert to Islam, just as he had threatened the Jews of Medina with the same fate several years earlier upon returning from Badr.

Here it is important to correct some gross inaccuracies in contemporary Islamic apologetics regarding Muhammad's conflict with the Jews. The standard Islamic apologetic line is that Muhammad's conflict with the Jews was purely political, not religious, and that it was caused solely by the Jews' treacherous collusion with Muhammad's enemies, the Quraysh, in Mecca. ${ }^{52}$ Both claims are inconsistent with the evidence contained in the sira. The conflict, as we have already seen, was at root religious, since it had to do with how to interpret the Torah. Moreover, Jewish collaboration with Muhammad's enemies in Mecca was more an effect than a cause of his aggression against the Jews. According to Ibn Ishaq, the Jews did not begin to collaborate with the Quraysh until after Muhammad's victory at Badr. ${ }^{53}$ As we have seen, since shortly after the move to Medina, Muhammad and the Muslims had been applying heavy pressure to the Jews to convert to Islam, insulting them by telling them they were lying about the Torah, and then, upon returning from Badr, finally telling them to convert to Islam or else be crushed militarily as the Quraysh had been crushed. Muhammad's message to the Jews right after Badr was not to stop collaborating with his enemies; indeed, Ibn Ishaq never depicts him as saying any such

52 See e.g. Reza Aslan, No god but God, pp. 89-92; Louay M. Safi, Peace and the Limits of War, pp. 21-2; Tariq Ramadan, In the Footsteps of the Prophet, pp. 107-9; Omid Safi, Memories of Muhammad, pp. 134-140; Karen Armstrong, Muhammad: A Biography of the Prophet (New York: HarperCollins, 1992), pp. 182-6. Daniel C. Peterson, Muhammad: Prophet of God (Grand Rapids MI and Cambridge UK: William B. Eerdmans Publishing Co., 2007), also puts the blame entirely on the Jews, ignoring much of the evidence from the sira cited in this paper.

53 The first clearly dated allegations of such collusion are at Guillaume, Life of Muhammad, p. 361 (the meeting of Sallam bin Mishkam of the Banu al-Nadir with Abu Sufyan during "the raid of al-sawiq" after Badr) and p. 365 (the Jewish poet Ka'b bin al-Ashraf went to Mecca only after Badr and "began to inveigh against the apostle"). On p. 265, there is a description of a meeting between some Jewish leaders from Banu Qurayza and Banu alNadir with the Quraysh, but the date of this meeting is unclear, and there is no mention of any collaboration in military action against Muhammad, nor is there any mention of the Banu Qaynuqa being present. The main point of the anecdote on p. 265 is that the Jews allegedly told the Quraysh that their polytheism was religiously superior to the strict monotheism of Islam - an extremely improbable allegation, like so many of Ibn Ishaq's charges against the Jews, e.g. the Jews say God is poor compared to them (p. 263), the Jews worship Ezra as the son of God (pp. 163, 269), etc. 


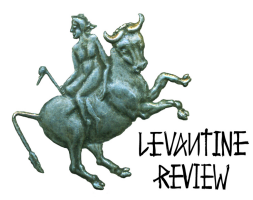

thing to them. Instead, his message to the Jews was that they must admit that he is a prophet foretold in the Torah, and become Muslims-or else. ${ }^{44}$ The Jews would understandably have regarded this as a blatant violation of the agreement they had entered with Muhammad after the hijra, the so-called "constitution of Medina," which Ibn Ishaq describes as "a friendly agreement with the Jews" that "established them in their religion" and stipulated that "the Jews have their religion and the Muslims have theirs."55 Muhammad was clearly no longer willing to allow the Jews to "have their religion." Any subsequent Jewish collaboration with Muhammad's enemies must be seen as a defensive reaction to Muhammad's threats and to his unilateral abrogation of the treaty that had protected the Jews' religious freedom.

Muhammad's first military action against the Jews was aimed at the tribe of the Banu Qaynuqa, of whom Ibn Ishaq says they "were the first to break their agreement with the apostle and go to war." 56 Yet nowhere does Ibn Ishaq allege that the Banu Qaynuqa had colluded with Muhammad's enemies (that charge is leveled at the Banu al-Nadir ${ }^{57}$ and then later at the Banu Qurayza, ${ }^{58}$ but not at the Banu Qaynuqa. ${ }^{59}$ ) It is only in the annotation of Ibn Ishaq's editor, Ibn Hisham, that we get any details about this alleged act of "breaking their agreement" and "going to war." According to Ibn Hisham, a Jew of the Banu Qaynuqa played a tasteless practical joke on a Muslim woman in the marketplace, pinning her dress so that, upon standing, she was "immodestly exposed." A fight broke out in which a Muslim and a Jew were killed. ${ }^{60}$ This was hardly an act of war. In fact it was precisely the sort of tribal conflict that Muhammad was supposed to mediate according to the "constitution of Medina." Muhammad used it, not as an occasion for peaceful mediation, but as a pretext for war against the Jews, a war driven by his anger at the Jewish refusal to accept him as a prophet. As W. Montgomery Watt notes, “The deeper reasons for Muhammad's action... are

54 Guillaume, The Life of Muhammad, pp. 260, 363.

55 Ibid., pp. 231-3.

56 Ibid., p. 363.

57 Ibid., p. 361.

58 Ibid., p. 453.

${ }^{59}$ Reza Aslan insinuates that the Banu Qaynuqa had tipped off the Quraysh about the Muslim expedition to Badr: No god but God, p. 89. Martin Lings makes a similar insinuation about the Jews in general in Muhammad: His Life Based on the Earliest Sources (Rochester VT: Inner Traditions, 1983), p. 160. However, Ibn Ishaq says no such thing, merely noting that Abu Sufyan, the leader of the Meccan caravan that Muhammad was aiming for, "got news from some riders that Muhammad had called out his companions against him and his caravan." Guillaume, The Life of Muhammad, p. 289. There is no indication that these riders were Jewish. It is hardly surprising that "some riders" should have noticed several hundred armed Muslim men travelling along the busy caravan routes between Mecca and Syria, clearly on a raiding expedition. 60 Guillaume, The Life of Muhammad, p. 751n568. 


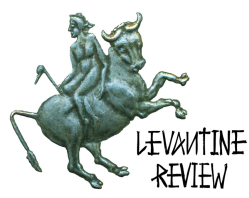

obvious. The Jews were not prepared to become full members of the Islamic community, and therefore he had broken with them."61 Indeed, if we ignore Ibn Hisham's later and presumably less reliable annotations and focus only on the text of Ibn Ishaq, it becomes quite clear that the battle with the Banu Qaynuqa was triggered not by a tasteless practical joke but by Muhammad's post-Badr ultimatum to the Jews to convert or be attacked. ${ }^{62}$

According to Ibn Ishaq, Muhammad had decided to go to war with the pagan Meccans even before he fled from Mecca in $622 .{ }^{63}$ Once in Medina, he almost immediately began ordering his men out on raids against the Meccans. ${ }^{64} \mathrm{He}$ knew that the Meccans would fight back, especially when they saw that their vital caravan routes were in danger of being cut off. Thus Muhammad was well aware that he had embarked on a life-or-death struggle with the powerful Quraysh of Mecca. His authority as a military commander depended on his claim to be a prophet: only if they accepted him as a prophet would his followers believe his assurances of eternal rewards in paradise as compensation for the painful sacrifices of war. ${ }^{65}$ However, his claim to be a prophet hinged on his assertion that the Jewish scriptures identified him clearly and by name as a prophet that the Jews, too, must follow. Indeed, a portion of the Koran proclaimed by Muhammad already in Mecca ${ }^{66}$ before the hijra insists that Muhammad is "the Apostle-the Unlettered Prophet-whom they shall find described to them in the Torah and the Gospel" (7:157). For Muhammad, it was a matter of infallible divine revelation that the Jews must acknowledge him as a prophet described in the Torah. In denying this claim, the Jews were undermining Muhammad's authority as a prophet and, consequently, as a political and military leader as well-a most serious threat, the more so since the rabbis were literate and Muhammad was not. It did not help matters that the rabbis were right about the Torah and Muhammad wrong. Unable to defeat the Jews intellectually, Muhammad tried to force them to embrace Islam, and when that failed, he set out to crush them physically. The Jews responded, too late and too ineffectually, by collaborating with Muhammad's enemies outside of Medina. Montgomery Watt gives the gist of the conflict with characteristic understatement:

The most important aspect of the break with the Jews was the intellectual. The Jews were attacking the whole set of ideas on which Muhammad's position was based. They declared that some of the things in the Qur'an contradicted the ancient scriptures in

61 W. Montgomery Watt, Muhammad: Prophet and Statesman (Oxford: Oxford University Press, 1961), p. 130. Cf. Rodinson, Muhammad, p. 172.

${ }^{62}$ Guillaume, The Life of Muhammad, p. 363.

63 Ibid., p. 221.

64 Ibid., p. 281.

65 See ibid. pp. 300-1 for examples of such promises made at Badr.

${ }^{66}$ Sura 7 is traditionally classified as a Meccan sura: see e.g. Syed Vickar Ahamed Holmdel trans., Interpretation of the Meaning of the Glorious Qur'an third ed. (Elmhurst NY: Tahrike Tarsile Qur'an, 2004), p. 99. 


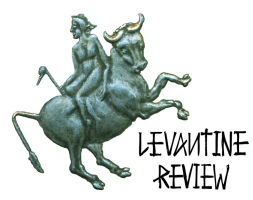

their hands, and must therefore be false; in that case, they could not be a revelation and Muhammad could not be a prophet. This was very serious. If many of the Muslims thought that what the Jews were saying was true, the whole structure of the community... would crumble away... The Jews were doing what they could to deprive [Muhammad] of... support, and as the possessors of the scriptures they were able to act effectively. ${ }^{67}$

Tor Andrae also points out that the Jewish counter-arguments "threatened completely to destroy Mohammed's religious authority." 68 While the Muslim sources demonize them, an impartial reader should be open to the possibility that the rabbis were merely telling the truth about what they found in their scriptures. They were in the wrong place at the wrong time and too honest for their own good. As Watt confirms, this was at root a theological (or "intellectual") disagreement. It became political and military only because the unique ideological threat posed by the rabbis made Muhammad feel that he had no choice but to abrogate his treaty with the Jews of Medina and go to war against them.

\section{FROM COMPULSION TO PRESSURE AGAINST PEOPLE OF THE BOOK: THE MEANING OF JIZYA}

Eventually Muhammad would accept something less than conversion from the Jews, both in Khaybar and elsewhere, subjugating them militarily and taking heavy tax payments from them in lieu of conversion to Islam. Muhammad would allow the Jews to stay in Khaybar on the condition that they turn over half their annual harvest to their Muslim overlords. His reasoning was strictly pragmatic: the Jews knew more about farming than the Muslims. ${ }^{69}$ In his massacre of the last Jewish tribe in Medina, the Banu Qurayza, one year earlier, Muhammad had learned that all but a handful of the Jews would accept death rather than convert to Islam..$^{70}$ What was the point of killing men who could be forced to work for the Muslims?

A short while after his conquest of Khaybar, Muhammad would be commanded by Sura 9:29 to fight the "people of the book," not only in the Hijaz, where he had already conquered them all, but presumably everywhere, "until they pay the poll-tax out of hand being humbled."71 The poll-tax or jizya is linked in this verse to the humbling of Jews and Christians, who deserve to be humbled due to their alleged religious perversity, for which

67 Watt, Muhammad: Prophet and Statesman, pp. 114-5

68 Tor Andrae, Mohammed: The Man and His Faith, Theophil Menzel trans. (New York: Charles Scribner's Sons, 1936), p. 192.

69 Guillaume, The Life of Muhammad, pp. 515-6.

70 Ibid., pp. 461-6; see pp. 94-5 for the three men who converted.

71 Ibid., p. 620. 


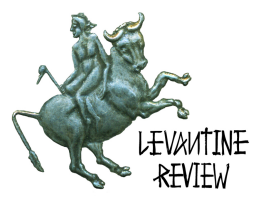

they are chastised in the immediately following verses (9:30-35)..$^{72}$ In traditional Arabian culture, honor is one of the most important values, and to be conquered and forced to pay tribute or protection money seriously diminishes one's honor. ${ }^{73}$ Within the three-fold context of Ibn Ishaq's entire narrative, the text of the Koran, and traditional Arabian culture, it is clear that the poll-tax or jizya was meant to punish and dishonor Jews and Christians for their alleged religious perversity and their refusal to convert to Islam. This may not be outright religious compulsion, but it certainly amounts to substantial pressure to convert to Islam, as subsequent Islamic history would prove. Indeed, Yohanan Friedmann writes that "the basic purpose of the jizya is to force People of the Book to embrace Islam." 74

${ }^{72}$ For philological evidence that verse 9:29 is calling for the humiliation of the people of the book, see Uri Rubin, "Quran and poetry: more data concerning the Quranic jizya verse," Jerusalem Studies in Arabic and Islam 31 (2006), pp. 139-46, and Raymond Ibrahim, Crucified Again: Exposing Islam's New War on Christians (Washington, DC: Regnery, 2013), p. 22. Ibrahim points out that the Arabic used in verse 9:29 (saghirun) connotes "to belittle, deride, ridicule, debase, demean." For evidence that later Islamic jurists linked the jizya to humiliation of Jews and Christians, see Joseph Schacht, An Introduction to Islamic Law (Oxford: Clarendon Press, 1982), p. 131; Bat Ye'or, The Dhimmi: Jews and Christians under Islam, David Maisel et al. trans. (Rutherford NJ: Fairleigh Dickinson University Press, 1985), pp. 53-4, 175-80, 188-9, 190-2, 201-2, and passim; Mark Durie, The Third Choice: Islam, Dhimmitude and Freedom (N.P.: Deror Books, 2010), pp. 131-41 and passim; Andrew Bostom ed., The Legacy of Jihad: Islamic Holy War and the Fate of Non-Muslims (Amherst, NY: Prometheus Books, 2005), pp. 169, 178-9, 199, 200, 202-4, 206, 216-20; Shaykh SafiurRahman Al-Mubarakpuri trans, Tafsir Ibn Kathir, second ed. (abridged) (Riyadh: Darussalam, 2003), Vol. 4, pp. 404-6 (commentary on verse 9:29). David Cook and Bernard Lewis also write that the purpose of the jizya was to humiliate: David Cook, Understanding Jihad (Berkeley: University of California Press, 2005), p. 60, and Bernard Lewis, The Jews of Islam (Princeton: Princeton University Press, 1984), pp. 14-15.

${ }^{73}$ Raphael Patai, The Arab Mind (New York: Charles Scribner's Sons, 1973), p. 90, and Philip Carl Salzman, Culture and Conflict in the Middle East (Amherst, NY: Prometheus Books, 2008), p. 106.

${ }^{74}$ Yohanan Friedmann, Tolerance and Coercion in Islam: Interfaith Relations in the Islamic Tradition (Cambridge: Cambridge University Press, 2003), pp. 99-100. On the humiliation attached to the jizya collection, Friedmann writes, "Reading the relevant material in the Muslim sources, one has frequently the impression that the humiliation of the unbeliever is more important than his conversion." Friedmann, Tolerance and Coercion in Islam, p. 37. Perhaps Friedmann would have done better to note that the humiliation was meant to induce conversion, as Fakhr al-Din al-Razi taught: see Jane Dammen McAuliffe, "Fakhr alDin al-Razi on ayat al-jizyah and ayat al-sayf," in Michael Gervers and Ramzi Jibran Bikhazi eds., Conversion and Continuity: Indigenous Christian Communities in Islamic Lands, Eighth to Eighteenth Centuries, Papers in Medieval Studies 9 (Toronto: Pontifical Institute of 


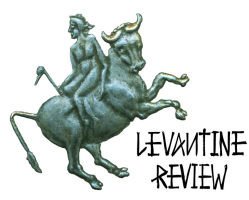

There is no evidence at all in Ibn Ishaq's sira suggesting that allowing "people of the book" to practice their faith in exchange for tax payments was based on a principled endorsement of religious liberty. On the contrary, the Koran and the sira state expressly that the justification of the jizya, in addition to the ideological goal of dishonoring Jews and Christians, is monetary. Verse 9:28, immediately preceding the jizya verse, commands Muslims no longer to allow pagans to make the pilgrimage to Mecca: "The polytheists are nothing but unclean, so let them not approach the sacred mosque after this year..."75 The problem is that pilgrims to the "sacred mosque" or Kaba in Mecca were a vital source of income for the Quraysh, Muhammad's tribe, who by this point had all converted to Islam. That is why the Koran 9:28 continues: "If you fear poverty God will enrich you from His bounty." In his gloss on this verse, Ibn Ishaq tells us, "that was because the people said 'the markets will be cut off from us, trade will be destroyed, and we shall lose the good things we used to enjoy..."'76 Then Ibn Ishaq quotes the jizya verse 9:29, concluding, "'... until they pay the poll tax out of hand being humbled,' i.e. as a compensation for what you fear to lose by the closing of the markets. God gave them compensation for what He cut off from them in their former polytheism by what He gave them by way of poll tax from the people of scripture."77 No doubt Muhammad had learned a useful lesson from the lucrative arrangement with the Jews of Khaybar. Instead of forcing the conversion of the Jews, he would allow them to keep their religion in return for making them an ongoing source of revenue for the nascent Islamic state. A no-doubt welcome side-effect of the humiliation and economic exploitation of "people of the book" would be steady pressure on them to convert to Islam. Since Muhammad had not shrunk from outright threats of violence against the Jews to get them to convert, he surely would have had no objection to this kind of pressure.

Medieval Studies, 1990), pp. 103-119 at p. 111. The jizya was also an onerous financial burden and this, too, induced conversion: see S. D. Goitein, A Mediterranean Society: The Jewish Communities of the Arab World as Portrayed in the Documents of the Cairo Geniza, Vol II, The Community (Berkeley: University of California Press, 1971), pp. 380-1; "The Jews Under Islam, Part I: $6^{\text {th }}-16^{\text {th }}$ Centuries," in Elie Kedourie ed., The Jewish World (London: Thames and Hudson, 1979), pp. 180-1; "Evidence on the Muslim Poll Tax from Non-Muslim Sources: A Geniza Study," Journal of the Economic and Social History of the Orient 6 (1963), pp. 278-295. For a vivid eye-witness description of the jizya collection in Morocco circa 1815, illustrating both the humiliation attached to it and its effect of inducing conversion, see James Riley, An Authentic Narrative of the American Brig Commerce: Wrecked on the Western Coast of Africa, in the Month of August, 1815 (Hartford: S. Andrus and Son, 1847), pp. 199-200.

${ }^{75}$ Guillaume, The Life of Muhammad, p. 620.

76 Ibid.

77 Ibid.

ISSN: 2164-6678 


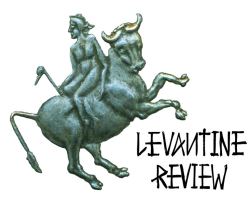

\section{COMPULSION AGAINST THE POLYTHEISTS}

With regard to the pagans of Arabia, however, Muhammad would adopt a harsher policy, presenting them with the stark choice of conversion or death shortly after his occupation of Mecca in 630. At the time of the surrender of Mecca, Ibn Ishaq recounts the conversion of the leading Meccan pagan Abu Sufyan, who was told, "Submit and testify that there is no God but Allah and that Muhammad is the apostle of God before you lose your head,' so he did so."78 Not surprisingly, the other pagans of the Quraysh tribe in Mecca fell in line behind Abu Sufyan and converted also: "Then the populace gathered together in Mecca to do homage to the apostle in Islam."79

Unlike the Jews, the polytheists were not inclined to choose martyrdom over apostasy. Religious compulsion was thus a realistic policy in their case. For example, a few months after the fall of Mecca, Ibn Ishaq tells us that,

...the apostle sent Khalid b. al-Walid... in the year 10 [AD 631] to the Banu al-Harith $b$. $K a ' b$ in Najran, and ordered him to invite them to Islam three days before he attacked them. If they accepted then he was to accept it from them; and if they declined he was to fight them. So Khalid set out and came to them, and sent out riders in all directions inviting the people to Islam, saying, "if you accept Islam you will be safe," so the men accepted Islam as they were invited. 80

The Banu al-Harith subsequently sent a delegation to Muhammad, and he told them, "If Khalid had not written to me that you had accepted Islam... I would throw your heads beneath your feet." 81 Here we see the implementation of the divine command given to Muhammad in verse 9:5 in March 631: "And when the sacred months are passed, then kill the polytheists wherever you find them, and seize them and besiege them and lie in wait for them in every ambush. But if they repent and perform prayer and pay the poor-tax, then let them go their way." 82 This verse commands the forced conversion of Arabian polytheists to Islam-a clear instance of religious compulsion. ${ }^{83}$

78 Ibid., p. 547.

79 Ibid., p. 553.

80 Ibid., p. 645.

81 Ibid., p. 646.

82 Ibid., pp. 618-9.

83 See F.E. Peters, Muhammad and the Origins of Islam, p. 244; Reuven Firestone, Jihad: The Origins of Holy War in Islam (New York and Oxford: Oxford University Press, 1999), pp. 889; David Cook, Understanding Jihad (Berkeley: University of California Press, 2005), p. 10; Uri Rubin, "Bara'a: A Study of Some Quranic Passages," Jerusalem Studies in Arabic and Islam 5 (1984), pp. 13-32; Uri Rubin, "The Great Pilgrimage of Muhammad: Some Notes on Sura IX," Journal of Semitic Studies 27 (1982), pp. 241-260; Ella Landau Tasseron, “Jihad,” in 


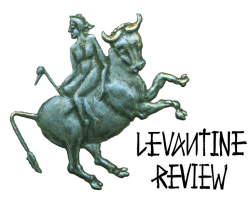

Another example from around the same time is Muhammad's treatment of the Thaqif in alTaif, who were forced to destroy their idol Al-Lat and convert to Islam to preserve their lives. ${ }^{84}$ The Muslim orator Thabit bin Qays bin al-Shammas stated Muhammad's policy clearly when ordered to speak on Muhammad's behalf and in Muhammad's presence to a visiting delegation from the Banu Tamim:

We are God's helpers and the assistants of His apostle, and will fight men until they believe in God; and He who believes in God and His apostle has protected his life and property from us; and he who disbelieves we will fight in God unceasingly and killing him will be a small matter to us. ${ }^{85}$

Muhammad's close companion Abu Bakr gives an accurate summary of Muhammad's career at the end of Ibn Ishaq's biography: "God sent Muhammad with this religion and he strove for it until men accepted it voluntarily or by force." 86 These passages in the sira are entirely consistent with a famous hadith according to which Muhammad said, "I was ordered to fight all men until they say "There is no God but Allah.'”87

\section{OTHER KINDS OF RELIGIOUS COMPULSION}

Another type of religious compulsion practiced by Muhammad was complete intolerance for anyone else's claim to be a prophet after his own career as a prophet had commenced. Muhammad said to his followers, "there will be no prophet after me."88 In Muhammad's own day, the man whom the Muslim tradition labels "Musaylima the liar" (or "arch-liar") claimed, like Muhammad, to be a prophet. The Muslim community's reaction was to go to war with him and kill him. ${ }^{89}$ As a result of this precedent, Islamic law does not permit the practice of any religion based on a revelation allegedly received after Muhammad's time, e.g. the religions of the Sikhs, Bahais, Mormons, or Ahmadis (also known as Qadianis). The jizya is only to be accepted from those who received an authentic scripture prior to the

The Encyclopedia of the Quran (Leiden: Brill, 2001-6), Vol. III, pp. 35-43 at p. 40: “Q 9:5 instructs the Muslims to fight the idolaters (mushrikun) until they are converted to Islam..." ${ }^{84}$ Guillaume, The Life of Muhammad, pp. 614-6.

85 Ibid., pp. 628-9.

86 Ibid., pp. 668-9.

${ }^{87}$ Efraim Karsh, Islamic Imperialism: A History (New Haven and London: Yale University Press, 2006), p. 1. Karsh's endnote traces this saying to Waqidi's Kitab al-Maghazi (p. 236n 10) (see Rizwi Faizer, The Life of Muhammad: Al-Waqidi's Kitab al-Maghazi, p. 544). It can also be found in Al-Misri, Reliance of the Traveller, p. 599, and Sahih Bukhari, Vol. 4, Book 52, No. 196.

88 Guillaume, The Life of Muhammad, p. 604.

89 Ibid., pp. 212, 377, 636, 648-9, 686. 


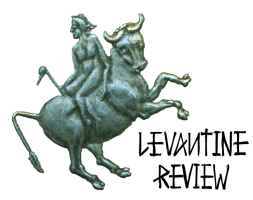

coming of the Koran, i.e. Jews, Christians, Zoroastrians, Samaritans, and Sabians. ${ }^{90}$ Indeed, today across the Islamic world, Bahais and Ahmadis are among the most harshly persecuted religious minorities. ${ }^{91}$

Between outright religious compulsion and purely voluntary conversion there were many degrees and kinds of pressure that led people to convert, both in Muhammad's day and after. The pressure of the jizya, discussed above, is one example, but Ibn Ishaq's sira contains many others. Thus, Muhammad adopted the policy of sparing any enemy who pronounced the shahada or Islamic profession of faith, even those on the verge of being killed. Ibn Ishaq tells us of a raid on which the Muslim fighter Usama bin Zayd was about to kill an enemy on the battlefield. The enemy fighter pronounced the shahada, but Usama killed him anyway. Upon hearing this, Muhammad chastised Usama, who protested: "I told him that the man had pronounced the words merely to escape death." 92 Muhammad insisted nonetheless that such men not be killed, and forced his soldiers to comply. (If American soldiers in Iraq or Afghanistan spared the lives of enemy fighters only on the condition that they convert to Christianity, would any of us hesitate to describe this as a form of religious compulsion?)

Of the Jewish tribe of the Banu al-Nadir, stripped of their farmland and expelled by Muhammad from Medina in 626, we are told that the only ones allowed to keep their property and remain in Medina were two men who converted to Islam. ${ }^{93}$ When the men of the Jewish Banu Qurayza were beheaded by the Muslims, and the women and children enslaved, three of the men "became Muslims and saved their lives, their property, and their families."94 After the Muslim victory at Hunayn in 630, the conquered Hawazin converted to Islam in order to escape enslavement and regain their wives and children, who also had been enslaved. ${ }^{95}$ Also after the battle of Hunayn, Muhammad sent word to the escaped enemy commander, Malik b. Auf, and told him "that if he came to him as a Muslim he would return his family and property to him and give him a hundred camels;" this was enough to induce Malik's conversion to Islam. ${ }^{96}$ Muhammad made a particular point of assassinating poets who mocked him in their verse, but pardoned them on the condition that they

90 Ahmad ibn Naqib al-Misri, Reliance of the Traveller, p. 607. See also Yohanan Friedmann, Tolerance and Coercion in Islam, pp. 8-9.

91 Paul Marshall and Nina Shea, Silenced: How Apostasy and Blasphemy Codes are Choking Freedom Worldwide (Oxford: Oxford University Press, 2011), pp. 83, 84, 86, 87, 89-92, 14953, 159-62, 169, 310 (on Ahmadis), and pp. 9, 41-6, 63-5, 310 (on Bahais).

92 Guillaume, Life of Muhammad, p. 667. See also p. 376: "He does not kill anyone who enters his religion and pronounces the shahada."

93 Ibid., p. 438.

94 Ibid., pp. 94-5.

95 Ibid., pp. 592-3.

96 Ibid., p. 593. 


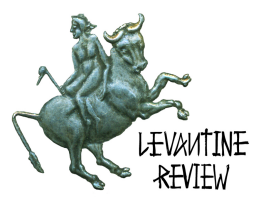

convert to Islam $\cdot{ }^{97}$ At the end of his life, Muhammad would order that all non-Muslims be expelled from the Arabian Peninsula- unless they converted to Islam. ${ }^{98}$ In other passages, too, Ibn Ishaq frankly acknowledges that fear of physical violence led many people to convert to Islam..$^{99}$

Consider one final example that pervades the entire sira. The very fact that there were "hypocrites" or insincere Muslims after the hijra but not before is highly significant. In Mecca before 622, conversion meant persecution by the pagan majority, so the only converts were true believers. But in Medina after 622, there were, Ibn Ishaq tells us, pagans "clinging to the polytheism of their fathers denying the resurrection; yet when Islam appeared... they were compelled to pretend to accept it to save their lives [emphasis added.]"100 Thus were the "hypocrites" born.

\section{SURA 109: "YOU HAVE YOUR RELIGION, AND I HAVE MINE"}

Sura 109 is another set of verses that might seem to convey an attitude of religious tolerance: "Say, O disbelievers, I do not worship what you worship, and you do not worship what I worship... You have your religion, and I have mine." According to Ibn Ishaq, these verses were revealed in Mecca before the hijra when Muhammad was in a position of weakness and when he was under pressure to adopt a syncretistic compromise with the polytheists who were persecuting him. A group of polytheists came to Muhammad and made this proposal: "Muhammad, come let us worship what you worship, and you worship what we worship.... If what you worship is better than what we worship we will take a share in it, and if what we worship is better than what you worship, you can take a share of that."101 Ibn Ishaq makes it clear that Muhammad's response was an emphatic rejection of any compromise between strict monotheism and the polytheism of the Quraysh. Ibn Ishaq places the revelation of Sura 109 in the context of the "Satanic verses," an episode that also led to an emphatic rejection of syncretism after a brief and mistaken flirtation with the idea by Muhammad. ${ }^{102}$ Sura 109 is not so much an endorsement of religious tolerance, therefore, as it is a rejection of syncretism. After all, it would be preposterous to suggest that Muhammad had no objection to Arabians retaining their allegiance to polytheism. Indeed, as we have seen, the revelation of 9:5 some years later (in 631) would entail

${ }^{97}$ Ibid., pp. 597-8; cf. 550-1. W. Montgomery Watt writes, "Throughout his career Muhammad was especially sensitive to intellectual or literary attacks. They were for him an unforgivable sin." To this I would add: they were forgivable, but only if the poet repented and converted to Islam. Watt, Muhammad: Prophet and Statesman, p. 123.

${ }_{98}$ Guillaume, Life of Muhammad, pp. 523, 525, 689.

${ }^{99}$ Ibid., pp. 239, 369, 628, 629-30, 676.

100 Ibid., p. 239.

101 Ibid., p. 165.

102 Ibid., pp. 165-7. 


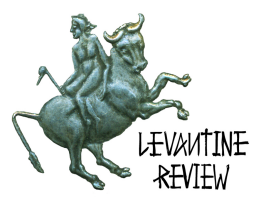

complete and total intolerance for any sort of polytheism in Arabia. These verses, therefore, do not really constitute a principled endorsement of religious tolerance or pluralism. ${ }^{103}$

\section{CONCLUSION}

So what does the Koran mean when it says, "there is no compulsion in religion?" In the entire biography of Muhammad, this verse is mentioned only once, and in a way that actually amounts to a threat of religious compulsion, and Muhammad's own practice clearly implies approval of many forms of religious compulsion. If Muhammad is the most authoritative interpreter of the Koran, and if the earliest extant biography of Muhammad is the most reliable guide to his thought and practice, then we must conclude that, whatever this verse means, it is not endorsing anything like our modern Western idea of religious liberty (or, if it is, then it has apparently been abrogated by later verses such as 9:5.) ${ }^{104}$

Fakhr al-Din al-Razi (1149-1209) offers one possible solution, stressing the definite article, "There shall be no compulsion in the religion," where by "the religion" he means both Islam and the scriptural traditions prior to Islam, but not paganism or polytheism (or presumably religions founded after Muhammad), where religious compulsion is entirely appropriate. ${ }^{105}$ A challenge for this interpretation of verse 2:256 is that Ibn Ishaq makes it quite clear that Muhammad was perfectly willing to compel the Jews to convert, and abandoned this policy only on pragmatic grounds, not as a matter of religious or moral principle. In fact, as we have seen, Ibn Ishaq's sole allusion to this verse comes at a time when Muhammad was still trying to compel conversion of the Jews and before he had decided to accept tax payments from the Jews in lieu of conversion.

103 See Yohanan Friedmann, Tolerance and Coercion in Islam, p. 88. One might say that Sura 109 does convey a pragmatically motivated and grudging acceptance of the fact of Arab polytheism as something that Muhammad was as yet powerless to eradicate. In this respect, classical exegetes considered the verses of sura 109 to have been abrogated by verse 9:5. See Powers, “The Exegetical Genre nasikh al-Quran wa mansukhuhu," pp. 137138. Reza Aslan cites verse 109:6 as endorsing religious tolerance and pluralism, but he says nothing about its context in the sira or its apparent abrogation by verse 9:5: see Aslan, No god but God, p. 85. So-called "Islamic radicals" like the Taliban have a more accurate understanding of Sura 109 and its context in Muhammad's life than do liberals like Aslan. See Tufail Ahmad, "The Terrorist Groups' Interpretation Of The Koranic Verses Regarding Jihad," Middle East Media Research Institute, Inquiry and Analysis Series Report No. 1098, June 4, 2014, Part VII “The Verses Regarding Moderation/Compulsion in Religion", http://www.memri.org/report/en/print8011.htm.

104 On the verses abrogated by 9:5 according to classical Muslim exegetes, which include 2:256, see Powers, "The Exegetical Genre nasikh al-Quran wa mansukhuhu," pp. 137-138. 105 Jane Dammen McAuliffe, "Fakhr al-Din al-Razi on ayat al-jizyah and ayat al-sayf," pp. 111-4. 


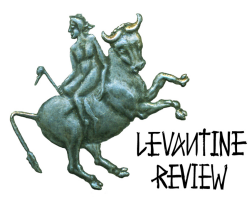

Another interpretation is suggested by Rudi Paret, who argues that this verse is not a prescription but an expression of resignation about the fact that the inner assent of faith cannot be compelled in the way that outward behavior can be. ${ }^{106}$ This interpretation is not clearly wrong and may even be right. After all, Muhammad compelled many people to convert, evincing no compunction at all about doing so, and, while seemingly content with outward conformity from his converts, he surely would have liked inner assent as well.

Perhaps the safest course, however, is to admit that we really do not know what this verse means. If verse 2:256 had played a major role in guiding the preaching and practice of Muhammad, one would expect to find evidence of this in the earliest extant biography of Muhammad, and such evidence could guide us in interpreting the verse. In fact, however, as we have seen, there is no evidence in the sira that verse 2:256 played much of a role if any in guiding Muhammad's own words or actions: the entire sira contains only one reference to this verse, and a highly equivocal one at that. It is worth noting as well that the secondmost important biography of Muhammad, al-Waqidi's Kitab al-Maghazi, does not contain even a single allusion to verse 2:256, but does contain numerous examples of religious compulsion by Muhammad and his companions. ${ }^{107}$ We must content ourselves with a negative conclusion: the verse, read in the context of the whole Koran and Muhammad's life, does not prescribe anything like the sort of religious tolerance that authors like Reza Aslan, Tariq Ramadan, Mahmud Shaltut, or Louay Safi want to read into it. One further conclusion would seem to be justified as well, namely, that when contemporary Islamists act intolerantly, the reason may be not that they are ignorant of the traditional biography of Muhammad, but all too familiar with it.

* Joseph S. Spoerl is a Professor in the Philosophy Department at Saint Anselm College in Manchester New Hampshire.

106 Rudi Paret, “Sure 2,256: la ikraha fi d-dini. Toleranz oder Resignation?", Der Islam 45 (1969), pp. 299-300. Paret applies the same interpretation to Koran 10:99. See also Yohanan Friedmann, Tolerance and Coercion in Islam, p. 94. 107 See note 7 , above. 


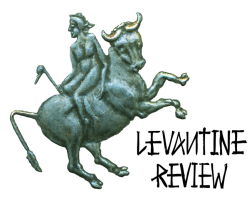

\section{Bibliography}

Ahmad, Tufail. “The Terrorist Groups' Interpretation Of The Koranic Verses Regarding Jihad." Middle East Media Research Institute, Inquiry and Analysis Series Report No. 1098, June 4, 2014. http://www.memri.org/report/en/print8011.htm.

Al-Misri, Ahmad ibn Naqib. Reliance of the Traveller: A Classic Manual of Islamic Sacred Law. $\mathrm{Nu}$ Ha Mim Keller ed. and trans. Revised Edition. Beltsville MD: Amana Publications, 1994.

Al-Mubarakpuri, Shaykh Safiur-Rahman, trans. Tafsir Ibn Kathir. Second edition (abridged). Riyadh: Darussalam, 2003.

Andrae, Tor. Mohammed: The Man and His Faith. Theophil Menzel trans. New York: Charles Scribner's Sons, 1936.

Armstrong, Karen. Muhammad: A Biography of the Prophet. New York: HarperCollins, 1992.

Aslan, Reza. No god but God: The Origins, Evolution, and Future of Islam. New York: Random House, 2005.

Bat Ye'or. The Dhimmi: Jews and Christians under Islam. David Maisel et al. trans. Rutherford NJ: Fairleigh Dickinson University Press, 1985.

Bostom, Andrew ed. The Legacy of Jihad: Islamic Holy War and the Fate of Non-Muslims. Amherst, NY: Prometheus Books, 2005.

Bukay, David. "Peace or Jihad? Abrogation in Islam," The Middle East Quarterly 14 (2007), pp. 3-11. http://www.meforum.org/1754/peace-or-jihad-abrogation-in-islam

Cook, David. Understanding Jihad. Berkeley: University of California Press, 2005.

Copi, Irving M. and Carl Cohen. Introduction to Logic. Eighth edition. New York: Macmillan, 1990.

Crone, Patricia and Michael Cook. Hagarism: The Making of the Muslim World. Cambridge: Cambridge University Press, 1980.

Dawood, N.J. trans. The Koran. Revised edition. Harmondsworth UK: Penguin Books, 1999. 


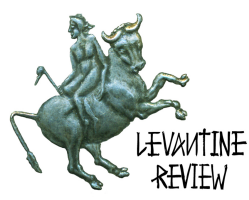

Donner, Fred. Muhammad and the Believers: At the Origins of Islam. Cambridge MA and London UK: The Belknap Press of Harvard University Press, 2010.

Durie, Mark. The Third Choice: Islam, Dhimmitude and Freedom. N.P.: Deror Books, 2010.

Esposito, John L. ed. The Oxford Encyclopedia of the Islamic World. Oxford: Oxford University Press, 2009.

Faizer, Rizwi ed. The Life of Muhammad: Al-Waqidi's Kitab al-Maghazi. Translated by Rizwi Faizer, Amal Ismail, and AbdulKader Tayob. London and New York: Routledge, 2011.

Firestone, Reuven. Jihad: The Origins of Holy War in Islam. New York and Oxford: Oxford University Press, 1999.

Friedmann, Yohanan. Tolerance and Coercion in Islam: Interfaith Relations in the Muslim Tradition. Cambridge: Cambridge University Press, 2003.

Gibb, H.A.R. ed. The Encyclopedia of Islam. Leiden: Brill, 1954.

Goitein, S. D. "Evidence on the Muslim Poll Tax from Non-Muslim Sources: A Geniza Study," Journal of the Economic and Social History of the Orient 6 (1963), pp. 278-295.

Goitein, S. D. A Mediterranean Society: The Jewish Communities of the Arab World as Portrayed in the Documents of the Cairo Geniza, Vol II, The Community. Berkeley: University of California Press, 1971.

Goitein, S. D. “The Jews Under Islam, Part I: $6^{\text {th }}-16^{\text {th }}$ Centuries,” in Elie Kedourie ed., The Jewish World (London: Thames and Hudson, 1979), pp. 178-185.

Guillaume, Alfred. The Life of Muhammad: A Translation of Ibn Ishaq's Sirat Rasul Allah. Oxford and Karachi: Oxford University Press, 1955.

Holmdel, Syed Vickar Ahamed trans. Interpretation of the Meaning of the Glorious Qur'an. Third edition. Elmhurst NY: Tahrike Tarsile Qur'an, 2004.

Ibrahim, Raymond. Crucified Again: Exposing Islam's New War on Christians. Washington, DC: Regnery, 2013.

Karsh, Efraim. Islamic Imperialism: A History. New Haven and London: Yale University Press, 2006. 


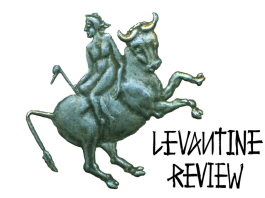

Khadduri, Majid ed. and trans. Al-Shafi's Risala: Treatise on the Foundations of Islamic Jurisprudence. Second edition. London: The Islamic Texts Society, 1987.

Lewis, Bernard. The Jews of Islam. Princeton: Princeton University Press, 1984.

Lings, Martin. Muhammad: His Life Based on the Earliest Sources. Rochester VT: Inner Traditions, 1983.

Marshall, Paul and Nina Shea. Silenced: How Apostasy and Blasphemy Codes are Choking Freedom Worldwide. New York and Oxford: Oxford University Press, 2011.

McAuliffe, Jane Dammen. "Fakhr al-Din al-Razi on ayat al-jizyah and ayat al-sayf," in Michael Gervers and Ramzi Jibran Bikhazi eds., Conversion and Continuity: Indigenous Christian Communities in Islamic Lands, Eighth to Eighteenth Centuries, Papers in Medieval Studies 9 (Toronto: Pontifical Institute of Medieval Studies, 1990), pp. 103-119.

Paret, Rudi. “Sure 2,256: la ikraha fi d-dini. Toleranz oder Resignation?”, Der Islam 45 (1969), pp. 299-300.

Patai, Raphael. The Arab Mind. New York: Charles Scribner's Sons, 1973.

Peters, F.E. "The Quest of the Historical Muhammad," International Journal of Middle East Studies 23 (1991), pp. 291-315.

Peters, F.E. Muhammad and the Origins of Islam. Albany: State University of New York Press, 1994.

Peters, Rudolph. Jihad in Classical and Modern Islam: A Reader. Princeton: Marcus Wiener, 1996.

Peterson, Daniel C. Muhammad: Prophet of God. Grand Rapids MI and Cambridge UK: William B. Eerdmans Publishing Co., 2007.

Powers, David S. "The Exegetical Genre nasikh al-Quran wa mansukhuhu," in Andrew Rippin ed., Approaches to the History of the Interpretation of the Quran (Oxford: Clarendon Press, 1988), pp. 117-138.

Ramadan, Tariq. In the Footsteps of the Prophet: Lessons from the Life of Muhammad. Oxford: Oxford University Press, 2007.

Riley, James. An Authentic Narrative of the American Brig Commerce: Wrecked on the Western Coast of Africa, in the Month of August, 1815. Hartford CT: S. Andrus and Son, 1847.

ISSN: 2164-6678 


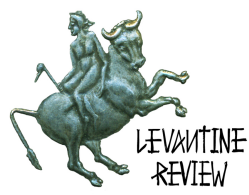

Rodinson, Maxime. Muhammad. Anne Carter trans. New York: The New Press, 1980.

Rubin, Uri. "The Great Pilgrimage of Muhammad: Some Notes on Sura IX," Journal of Semitic Studies 27 (1982), pp. 241-260.

Rubin, Uri. “Bara'a: A Study of Some Quranic Passages," Jerusalem Studies in Arabic and Islam 5 (1984), pp. 13-32.

Rubin, Uri. "Quran and poetry: more data concerning the Quranic jizya verse," Jerusalem Studies in Arabic and Islam 31 (2006), pp. 139-46.

Safi, Louay M. Peace and the Limits of War: Transcending the Classical Conception of Jihad. Second edition. London and Washington: The International Institute of Islamic Thought, 2003.

Safi, Omid. Memories of Muhammad: Why the Prophet Matters. New York: HarperCollins, 2009.

Sahih Bukhari, trans. M. Muhsin Khan.

http://www.usc.edu/schools/college/crcc/engagement/resources/texts/muslim/hadith/ bukhari/

Salzman, Philip Carl. Culture and Conflict in the Middle East. Amherst NY: Prometheus Books, 2008.

Spoerl, Joseph S. "Islam and War: Tradition vs. Modernity," Comparative Islamic Studies 4 (2008), pp. 181-212.

Spoerl, Joseph S. "Muhammad and the Jews According to Ibn Ishaq," The Levantine Review 2 (2013), pp. 84-103. http://ejournals.bc.edu/ojs/index.php/levantine/article/view/5084

Tasseron, Ella Landau. "Jihad," in The Encyclopedia of the Quran (Leiden: Brill, 2001-6), Vol. III, pp. 35-43.

Watt, W. Montgomery. Muhammad: Prophet and Statesman. Oxford: Oxford University Press, 1961.

Watt, W. Montgomery. Early Islam: Collected Articles. Edinburgh: Edinburgh University Press, 1990. 